\title{
Kemampuan Pemecahan Masalah Matematika Ditinjau Dari Minat Belajar Peserta Didik
}

\author{
Ikha Yuliati \\ Program Studi Pendidikan Guru Madrasah Ibtidaiyah, Fakultas Tarbiyah, Institut Agama Islam Negeri Madura, \\ Jl. Raya Panglegur No.Km. 4, Barat, Ceguk, Tlanakan, Kabupaten Pamekasan, Jawa Timur 69371 \\ ikhayuliati93@iainmadura.ac.id
}

\begin{abstract}
The ability of students to solve mathematical problems is a provision for facing current developments, while the students' interest in learning mathematics is still relatively low. This study aims to determine the effect of students' interest in learning on students' mathematical problem solving's abilities and how the relationship between students' interest in learning and mathematical problem solving's abilities. The research was conducted on students of class VIII MTs Daarul Hikmah Kota Tangerang Selatan and MTs Mathlaul Anwar Kota Tangerang Selatan. The research hypothesis tested was the influence of students' interest in learning on the ability to solve mathematical problems and the relationship between students' interest in learning and students' mathematical problem solving's abilities. The research was conducted using a correlational method with a quantitative approach. Data analysis used linear regression using SPSS 23 softwawe calculation. The results of hypothesis testing concluded that there was a significant influence on students' interest in learning on mathematical problem solving's abilities. Evidenced by sig. $0.000<0.05$ and $\mathrm{Fh}=203.459>\mathrm{Ftab}=0.004$. We need an active role of teachers and parents/guardians of students to supervise students 'interest in learning in order to improve students' skills in solving math problems.
\end{abstract}

Keywords: learning interest, ability to solve mathematical problems.

\begin{abstract}
Abstrak
Kemampuan pemecahan masalah matematika peserta didik menjadi bekal dalam menghadapi perkembangan zaman saat ini, sementara minat belajar matematika peserta masih terbilang rendah. Penelitian ini bertujuan untuk mengetahui pengaruh minat belajar peserta didik terhadap kemampuan pemecahan masalah matematika peserta didik dan bagaimana hubungan antara minat belajar peserta didik terhadap kemampuan pemecahan masalah matematika. Penelitian dilakukan pada peserta didik kelas VIII MTs Daarul Hikmah Kota Tangerang Selatan dan MTs Mathlaul Anwar Kota Tangerang Selatan. Hipotesis penelitian yang diuji yaitu pengaruh minat belajar peserta didik terhadap kemampuan memecahkan masalah matematika dan hubungan antara minat belajar peserta didik dengan kemampuan pemecahan masalah matematika peserta didik. Penelitian dilakukan dengan metode korelasional dengan pendekatan kuantitatif. Analisis data menggunakan regresi linier dengan menggunakan penghitungan softwawe SPSS 23. Hasil pengujian hipotesis menyimpulkan bahwa terdapat pengaruh yang signifikan minat belajar peserta didik terhadap kemampuan pemecahan masalah matematika. Dibuktikan dengan sig. $0,000<0,05$ dan $\mathrm{Fh}=203,459>\mathrm{Ftab}=0,004$. Oleh karena itu diperlukan peran aktif guru dan orang tua/wali murid untuk mengawasi minat belajar peserta didik guna meningkatkan keterampilan didik peserta didik dalam memecahkan persoalan matematika.
\end{abstract}

Kata kunci: minat belajar, kemampuan pemecahan masalah matematika

Copyright (c) 2021 Ikha Yuliati

Corresponding author: Ikha Yuliati

Email Address: ikhayuliati93@iainmadura.ac.id (Jl. Raya Panglegur No.Km. 4, Barat, Ceguk, Tlanakan)

Received 09 March 2021, Accepted 22 April 2021, Published 04 May 2021

\section{PENDAHULUAN}

Ilmu dan teknologi telah mengalami perkembangan begitu pesat di era globalisasi saat ini dan telah berdampak pada berbagai bidang kehidupan, tak tekecuali pada bidang pendidikan. Pemanfaatan teknologi dalam berbagai sistem kehidupan tidak hanya memberikan kemudahan bagi peradaban manusia namun juga dapat menimbulkan permasalahan baru bila tidak diiringi dengan sumber daya manusia yang juga mempuni secara mental dan intelegensi. Untuk itu, perlu dipersiapakan generasi yang 
tak hanya berpengetahuan, namun juga sikap yang tangguh dan memiliki kemampuan dalam menghadapi persoalan era yang terus berkembang. Matematika sangat erat kaitannya dengan proses pemecahan masalah (Ulya 2015), sebab matematika merupakan disiplin ilmu eksak yang membutuhkan penalaran dan berpikir kreatif dalam memahami suatu teorema (Agustin and Hartanto 2018). Kemampuan peserta didik dalam menyelesaikan masalah matematika merupakan bekal dalam menghadapi era globalisasi dimasa akan datang (Hermaini and Nurdin 2020). Maka dari itu, matematika menjadi salah satu mata pelajaran yang diharapkan dapat membentuk peserta didik memiliki kemampuan dalam memecahkan masalah baik dalam persoalan matematika maupun dalam persoalan sehari-hari, sehingga matematika telah diajarkan sejak jenjang pendidikan sekolah dasar hinga jenjang pendidikan perguruan tinggi.

Berbanding terbalik dengan peran penting di atas, faktanya matematika terkenal sebagai pelajaran yang tidak disenangi oleh kebanyakan peserta didik karena dianggap sulit, menakutkan dan membuat pusing dan stress (Nisrina 2018). Hasil Survei pada tahun 2018 yang dilakukan oleh salah satu program internasional yang mengukur tingkat keberhasilan pendidikan di suatu suatu negara yaitu Programme for Internasional Students Assessment (PISA) menyatakan bahwa pada kategori matematika, Indonesia berada di peringkat 7 dari bawah (peringkat 73 dari 79 negara) dengan skor rata-rata 379 (Hermaini and Nurdin 2020). Menurut hasil penelitian Hanifah yang melibatkan 36 peserta didik kelas VII pada salah satu SMP Negeri di Kabupaten Karawang didapati bahwa kemampuan pemecahan masalah matematika peserta didik masih belum maksimal begitupun dengan hasil penelitian Yonandi yang melibatkan 244 peserta didik kelas XI dari dua SMA negeri di Tasikmalaya menjelaskan bahwa kemampuan pemecahan masalah matematika pada tiap sekolah tersebut tergolong sangat rendah (Yuliasari 2017). Maka dari itu perlu dilakukan upaya untuk meningkatkan kemampuan pemecahan masalah matematika dengan melihat faktor apa saja yang mempengaruhi kemampuan pemecahan masalah peserta didik.

Salah satu penyebab rendahnya kemapuan pemecahan masalah matematika peserta didik yaitu kurangnya minat peserta didik untuk belajar matematika karena menganggap matematika terlalu memiliki banyak rumus yang harus dipahami (Kurnia et al. 2020). Minat belajar dapat diartikan sebagai ketertarikan seseorang untuk terlibat sepenuhnya terhadap suatu hal dengan cara menuangkan seluruh pikiran dan perhatiannya untuk memperoleh pengetahuan dan mencapai pemahaman tentang pengetahuan yang dituntutnya tanpa ada paksaan dari luar (Awaliyah and Fitrianna 2018). Minat belajar matematika menjadi salah satu faktor penting yang mempengaruhi penguasaan konsep matematika dalam memecahkan masalah matematika (Holidun et al. 2018). Tanpa adanya minat dalam diri peserta didik maka akan sulit untuk mengembangkan keinginan peserta didik dalam belajar matematika (Mayasari 2019), sebab minat ini yang akan mendorong peserta didik untuk terus berusaha mencari strategi dengan mengerahkan segala kemampuannya untuk menghasilkan ide-ide kreatif untuk menemukan solusi pemecahan masalah matematika (Partayasa, Suharta, and Suparta 2020). Dengan begitu, peserta didik dengan minat yang tinggi terhadap matematika akan memotivasinya untuk mempelajari secara berulang-ulang tanpa merasa terpaksa sehingga dapat meningkatkan 
kemampuannya dalam memecahkan masalah matematika.

Berdasarkan latar belakang inilah, maka peneliti tertarik untuk melakukan penelitian yang berjudul: "Kemampuan Pemecahan Masalah Matematika Melalui Minat Belajar Peserta Didik (Survei pada Siswa Kelas VIII MTS Swasta Kecamatan Pamulang Kota Tangerang Selatan), untuk menjawab pertanyaan penelitian: apakah terdapat pengaruh minat belajar peserta didik terhadap kemampuan pemecahan masalah matematika peserta didik dan bagaimana hubungan antara minat belajar peserta didik terhadap kemampuan pemecahan masalah matematika?

\section{METODE}

Dalam penelitian ini digunakan metode korelasional dengan pendekatan kuantitatif. Populasi penelitian ini adalah seluruh peserta didik kelas VIII MTs Daarul Hikmah (berjumlah 212) dan peserta didik kelas VIII MTs Mathlaul Anwar (161 peserta didik) Kota Tangerang Selatan pada tahun ajaran 2018/2019. Alasan pemilihan tempat penelitian tersebut karena masih rendahnya nilai Ujian Nasional Matematika pada peserta didik MTs dibandingkan peserta didik SMP di kecamatan Pamulang Kota Tangerang Selatan. MTs Swasta dipilih untuk dijadikan tempat penelitian karena hanya ada 1 MTs Negeri di kecamatan Pamulang Kota Tangerang Selatan dengan memperhatikan kesetaraan akreditasi sekolah pada tiap MTs swasta di kecamatan Pamulang Kota Tangerang Selatan. Teknik pengambilan sampel dalam penelitian ini menggunakan teknik Proporsional Cluster Random Sampling, karena populasi terdiri dari 2 sekolah, maka jumlah sampel yang diambil pada tiap sekolah dihitung dengan menggunakan rumus:

Keterangan:

$$
\mathrm{ni}=\frac{N i n}{N}
$$

$$
\begin{array}{ll}
\mathrm{ni} & =\text { jumlah sampel pada tiap sekolah } \\
\mathrm{Ni} & =\text { jumlah populasi pada tiap sekolah } \\
\mathrm{n} & =\text { jumlah populasi terjangkau }
\end{array}
$$

Adapun jumlah sampel yang digunakan yaitu 79 peserta didik dengan rincian sebagai berikut :

Tabel 1. Data jumlah penelitian

\begin{tabular}{|c|c|c|c|}
\hline No & Sekolah & Jumlah Peserta Didik Kelas VIII & Jumlah Sampel \\
\hline 1 & MTs Daarul Hikmah & 212 & 45 \\
\hline 2 & MTs Mathlaul Anwar & 161 & 34 \\
\hline \multicolumn{2}{|c|}{ Total } & 373 & 79 \\
\hline
\end{tabular}

Data kemampuan pemecahan masalah matematika diperoleh dengan instrument penelitian berupa soal essay pada pokok bahasan Sistem Persamaan Linear Dua Variabel (SPLDV). Sebelumnya telah dilakukan uji pada instrument berupa uji validitas, uji reliabilitas, uji tingkat kesukaran dan uji daya beda. Uji validitas dilakukan untuk mengetahui ketepatan alat ukur terhadap konsep yang diukur dengan menggunakan korelasi product moment dengan rumus : 


$$
r_{x y}=\frac{N \sum X Y-\left(\sum X\right)\left(\sum Y\right)}{\sqrt{N \sum X^{2}-\left(\sum X\right)^{2}} \sqrt{N \sum Y^{2}-\left(\sum Y\right)^{2}}}
$$

Keterangan:

$r_{x y} \quad$ : koefisien korelasi product moment antara variabel $\mathrm{X}$ dan variabel $\mathrm{Y}$

$\mathrm{N} \quad$ : banyaknya responden

Uji reliabilitas dilakukan untuk mengetahui konsistensi interval antar variabel dan instrument dengan menggunakan rumus:

$$
\mathrm{r}=\left(\frac{k}{k-1}\right)\left(\frac{S_{t}^{2}-\sum S_{i}^{2}}{S_{t}^{2}}\right)
$$

Keterangan :

$\mathrm{r} \quad$ : koefisien reliabilitas dengan rumus cronbach alpha

$\mathrm{S}_{\mathrm{i}} \quad$ : simpangan baku butir tes ke-i

$\mathrm{S}_{\mathrm{t}} \quad$ : simpangan baku seluruh butir tes

k : banyaknya butir soal yang valid

Uji tingkat kesukaran butir digunakan untuk melihat proporsi dari subjek yang menjawab butir soal dengan benar. Tingkat kesukaran diuji dengan menggunakan rumus :

$$
\mathrm{TK}=\frac{J B_{A}+J B_{B}}{2 J S}
$$

Keterangan :

TK : tingkat kesukaran

$J B_{A} \quad$ : jumlah skor responden kelompok atas

$J B_{B} \quad$ : jumlah skor responden kelompok bawah

JS : Jumlah skor max ideal pada salah satu kelompok

Uji daya pembeda soal dilakukan untuk menguji kemampuan suatu soal dalam membedakan antara peserta didik berkemampuan tinggi dengan peserta didik berkemampuan rendah dengan menggunakan rumus :

$$
\mathrm{DB}=\frac{J B_{A}-J B_{B}}{J S}
$$

Keterangan :

DB : Indeks daya pembeda

$J B_{A} \quad$ : Jumlah skor responden kelompok atas

$J B_{B} \quad$ : Jumlah skor responden kelompok bawah

JS : Jumlah skor max ideal pada salah satu kelompok

Adapun indikator instrument kemampuan pemecahan masalah matematika (Roebyanto and Harmini 2017) sebagai berikut:

- Memahami masalah, meliputi kemampuan:

- mengidentifikasi kecukupan data untuk memecahkan masalah;

- membuat model matematika dari suatu situasi atau masalah sehari-hari 
- Menyelesaikan masalah, meliputi kemampuan:

- memilih dan menerapkan strategi untuk menyelesaikan model atau masalah matematika dan atau di luar matematika;

- menerapkan matematika secara bermakna

- Menjawab masalah, meliputi kemampuan:

- menjelaskan atau menginterpretasikan hasil sesuai permasalahan asal

- memeriksa kebenaran hasil atau jawaban

Data minat belajar diperoleh dengan instrument penelitian berupa angket/kuesioner yang terdiri dari 10 pernyataan positif dan 10 pernyataan negatif. Sebelumnya telah dilakukan uji pada instrument tersebut berupa uji validitas dan uji reliabilitas. Adapun indikator instrument minat belajar menurut Lestari dan Mokhamad (Friantini and Winata 2019) sebagai berikut:

Tabel 2. Kisi-kisi Instrumen Minat Belajar

\begin{tabular}{|c|c|c|c|c|c|}
\hline \multirow{2}{*}{ Variabel } & \multirow{2}{*}{ Indikator } & \multirow{2}{*}{ Sub Indikator } & \multicolumn{2}{|c|}{ No. Soal } & \multirow{2}{*}{ Jumlah } \\
\hline & & & + & - & \\
\hline \multirow{11}{*}{$\begin{array}{l}\text { Minat } \\
\text { belajar } \\
\text { siswa }\end{array}$} & \multirow{5}{*}{$\begin{array}{l}\text { Rasa } \\
\text { tertarik, } \\
\text { senang dan } \\
\text { bersemangat } \\
\text { untuk } \\
\text { belajar }\end{array}$} & 1. Tertarik dengan materi pelajaran & 1 & 3 & 2 \\
\hline & & $\begin{array}{l}\text { 2. Selalu bersemangat dalam mengikuti } \\
\text { proses pembelajaran }\end{array}$ & 2 & 4 & 2 \\
\hline & & $\begin{array}{l}\text { 3. Merasa senang jika mendapatkan tugas } \\
\text { sekolah }\end{array}$ & 5 & 8 & 2 \\
\hline & & $\begin{array}{l}\text { 4. Merasa sedih jika tidak mengikuti } \\
\text { pembelajaran di kelas }\end{array}$ & 9 & 13 & 2 \\
\hline & & $\begin{array}{l}\text { 5. Merasa kecewa jika guru bersangkutan } \\
\text { tidak hadir }\end{array}$ & 6 & 16 & 2 \\
\hline & \multirow{5}{*}{$\begin{array}{l}\text { Kegiatan } \\
\text { belajar }\end{array}$} & $\begin{array}{l}\text { 1. Selalu senang mengikuti ujian untuk } \\
\text { mengetahui seberapa tinggi } \\
\text { kemampuannya menguasai materi } \\
\text { pelajaran }\end{array}$ & 7 & 17 & 2 \\
\hline & & $\begin{array}{l}\text { 2. Merasa betah belajar di kelas saat } \\
\text { pembelajaran berlangsung }\end{array}$ & 10 & 18 & 2 \\
\hline & & $\begin{array}{l}\text { 3. Selalu berusaha memahami pelajaran } \\
\text { yang diperoleh saat kegiatan } \\
\text { pembelajaran berlangsung }\end{array}$ & 11 & 19 & 2 \\
\hline & & $\begin{array}{l}\text { 4. Selalu bertanya kepada guru apabila } \\
\text { mendapatkan hal yang sulit dimengerti. }\end{array}$ & 12 & 20 & 2 \\
\hline & & $\begin{array}{l}\text { 5. Suka mengerjakan tugas individu tanpa } \\
\text { mencontek }\end{array}$ & 14 & 15 & 2 \\
\hline & & Jumlah Item & 10 & 10 & 20 \\
\hline
\end{tabular}

Selanjutnya dilakukan uji persyaratan analisis berupa uji normalitas dan uji linearitas dengan menggunakan SPSS 23. Uji normalitas bertujuan untuk mengetahui apakah data hasil pengumpulan berdistribusi normal atau tidak sebagai syarat jika pengujian menggunakan statistik parametrik dan uji normalitas dilakukan dengan menggunakan analisis Kolmogorov Smirnov (Suparman 2014). Distribusi 
data dikatakan normal jika nilai sig.KS $>0,05$. Uji persyaratan analisis selanjutnya adalah uji linearitas, dilakukan untuk mengetahui dan membuktikan bahwa hubungan antar variabel yang diteliti memiliki hubungan yang linear, dengan kriteria pengujian akan terima $\mathrm{H}_{0}$ jika Sig.> 0,05 dan tolak $\mathrm{H}_{0}$ jika Sig. < 0,05 .

Teknik analisis data menggunakan analisis regresi linear sederhana dengan variabel bebas adalah minat belajar dan variabel terikat adalah kemampuan pemecahan masalah matematis peserta didik. Analisis regresi linear dengan satu variabel bebas memiliki bentuk persamaan (Supardi 2017):

$$
Y=a+b X
$$

Keterangan:

$Y=$ variabel dependent / kriteria (yang diprediksikan)

$a=$ konstanta (harga $\mathrm{Y}$ untuk $\mathrm{X}=0$ )

$\mathrm{b}=$ angka arah (koefisien regresi)

$\mathrm{x}=$ variabel independent (prediktor)

Perhitungan analisis data dalam penelitian ini menggunakan program SPSS 23 (Mutakin, T.Z., \& Cleopatra 2015), sehingga dapat diketahui apakah terdapat pengaruh minat belajar terhadap kemampuan pemecahan masalah matematika peserta didik dan untuk mengetahui bagaimana hubungan antara minat belajar terhadap kemampuan pemecahan masalah matematika peserta didik. Berdasarkan perhitungan analisis data yang dilakukan, juga dapat diketahui besarnya koefisien korelasi (R) dan besarnya koefisien daterminasi linear $\left(\mathrm{R}^{2}\right)$ antara variabel bebas dan variabel terikat, sehingga akan diperoleh kesimpulan dari uji analisis yang dilakukan.

\section{HASIL DAN DISKUSI}

Sebelum dilakukan uji analisis regresi linear sederhana, terlebih dahulu dilakukan uji persyaratan analisis berupa uji normalitas dan linearitas. Hasil uji normalitas kedua variabel dalam penelitian ini (minat belajar dan kemampuan pemecahan masalah matematika) adalah berdistribusi normal dengan ringkasan hasil sebagai berikut:

Tabel 3. Rangkuman hasil uji normalitas

\begin{tabular}{|c|c|c|c|}
\hline Variabel & Skor KS-Z & Sig. & Simpulan \\
\hline Minat Belajar & 0,494 & 0,967 & Berdistribusi normal \\
\hline $\begin{array}{l}\text { Kemampuan Pemecahan Masalah } \\
\text { Matematika }\end{array}$ & 0.556 & 0,917 & Berdistribusi normal \\
\hline
\end{tabular}

Berdasarkan Tabel 3. terlihat bahwa nilai Sig. untuk variabel minat belajar dan kemampuan pemecahan masalah matematika secara berurutan adalah 0,967 dan 0,917. Karena nilai Sig. > 0,05 maka minat belajar dan kemampuan pemecahan masalah matematika berdistribusi normal. Sementara hasil uji 
linearitas kedua variabel dalam penelitian ini (minat belajar dan kemampuan pemecahan masalah matematika) sebagai berikut:

Tabel 4. Rangkuman hasil uji linearitas

\begin{tabular}{|l|l|l|l|}
\hline Garis yang diuji & Skor $\mathbf{F}$ & Sig. & Simpulan \\
\hline $\mathbf{X}$ atas $\mathbf{Y}$ & 0,849 & 0,668 & $\begin{array}{l}\text { Model regresi berpola } \\
\text { linear }\end{array}$ \\
\hline
\end{tabular}

Berdasarkan Tabel 4. diperoleh nilai signifikansi Deviation from Linearity sebesar 0,668. Karena nilai sig. > 0,05, maka variabel minat belajar dan kemampuan pemecahan masalah matematika berpola linear.

Kemudian dilakukan uji hipotesis dengan menggunakan uji analisis regresi linear sederhana. Adapun hasil dari uji analisis, dirangkum pada tabel berikut:

Tabel 5. Koefisien Variabel

Coefficients ${ }^{\mathrm{a}}$

\begin{tabular}{|c|c|c|c|c|c|}
\hline \multirow[b]{2}{*}{ Model } & \multicolumn{2}{|c|}{$\begin{array}{l}\text { Unstandardized } \\
\text { Coefficients }\end{array}$} & \multirow{2}{*}{$\begin{array}{c}\begin{array}{c}\text { Standardized } \\
\text { Coefficients }\end{array} \\
\text { Beta }\end{array}$} & \multirow[b]{2}{*}{$\mathrm{t}$} & \multirow[b]{2}{*}{ Sig. } \\
\hline & $\mathrm{B}$ & $\begin{array}{l}\text { Std. } \\
\text { Error }\end{array}$ & & & \\
\hline 1 (Constant) & 29.831 & 2.298 & & 12.980 & .000 \\
\hline $\begin{array}{l}\text { Minat } \\
\text { Belajar }\end{array}$ & 2.397 & .168 & .852 & 14.264 & .000 \\
\hline
\end{tabular}

Berdasarkan Tabel 5, diperoleh diperoleh nilai koefisien dari variabel minat belajar (X) sebesar 2,397 dan nilai konstannya 29,831. Sehingga diperoleh persamaan regresi: $Y=29,831+2,397 X$, yang artinya bahwa setiap kenaikan satu nilai minat belajar akan diikuti dengan kenaikan kemampuan pemecahan masalah matematika sebesar 2,397.

Tabel 6. Rangkuman Hasil Anova

ANOVA $^{\mathrm{a}}$

\begin{tabular}{|l|r|r|r|r|r|}
\hline \multicolumn{1}{|c|}{ Model } & $\begin{array}{c}\text { Sum of } \\
\text { Squares }\end{array}$ & df & $\begin{array}{c}\text { Mean } \\
\text { Square }\end{array}$ & \multicolumn{1}{c|}{ F } & Sig. \\
\hline 1 Regression & 3920.462 & 1 & 3920.462 & 203.459 & $.000^{\mathrm{b}}$ \\
Residual & 1483.715 & 77 & 19.269 & & \\
Total & 5404.177 & 78 & & & \\
\hline
\end{tabular}

a. Dependent Variable: Minat Belajar

b. Predictors: (Constant), KPMM

Berdasarkan Tabel 6. diperoleh hasil $F_{\text {hitung }}=203,459>F_{\text {Tabel }}=0,004$, sementara nilai Sig. $=0,000<$ 0,005. Karena $F_{\text {hitung }}>F_{\text {Tabel }}$ dan nilai Sig. $=0,000<0,005$, maka $H_{0}$ ditolak. Dengan demikian dapat disimpulkan bahwa terdapat pengaruh yang signifikan minat belajar peserta didik terhadap kemampuan pemecahan masalah matematika peserta didik. 
Hal ini sejalan dengan penelitian sebelumnya yang menerangkan bahwa minat belajar memiliki pengaruh yang signifikan terhadap kemampuan pemecahan masalah matematika pada peserta didik kelas VIII SMPN 2 Kauman (Agustin and Hartanto 2018). Dengan kata lain, untuk mengoptimalkan kemampuan pemecahan masalah matematika yang dimiliki peserta didik, salah satunya adalah dengan meningkatkan minat belajar peserta didik. Dalam penelitian lain dikatakan bahwa peserta didik yang tidak memiliki minat belajar dalam dirinya, maka mustahil peserta didik tersebut menyelesaikan suatu pemecahan masalah matematika (Nisrina 2018). Hal ini disebabkan peserta didik tidak memiliki hasrat dan ketertarikan untuk mengoptimalkan upayanya dalam belajar sehingga kesulitan dalam memecahkan suatu persoalan khususnya matematika dan berdampak pada rendahnya kemampuan peserta didik dalam memecahkan masalah matematika.

Untuk melihat seberapa besar pengaruh minat belajar terhadap kemampuan pemecahan masalah matematika peserta didik, dilakukan uji korelasi seperti yang disajikan pada tabel berikut:

Tabel 7. Rangkuman Korelasi

Model Summary

\begin{tabular}{|l|r|r|r|r|}
\hline Model & $\mathrm{R}$ & $\begin{array}{c}\mathrm{R} \\
\text { Square }\end{array}$ & $\begin{array}{c}\text { Adjusted } \\
\mathrm{R} \\
\text { Square }\end{array}$ & $\begin{array}{c}\text { Std. } \\
\text { Error of } \\
\text { the } \\
\text { Estimate }\end{array}$ \\
\hline 1 & $.852^{\mathrm{a}}$ & .725 & .722 & 4.390 \\
\hline
\end{tabular}

a. Predictors: (Constant), KPMM

Berdasarkan Tabel 7. diperoleh nilai koefisien korelasinya sebesar 0,852 dengan $\mathrm{R}^{2}=0,725$, sehingga nilai koefisien determinasinya sebesar 72,5\%. Hal ini menunjukkan bahwa besarnya kontribusi minat belajar terhadap kemampuan pemecahan masalah matematika peserta didik sebesar 72,5\%, sisanya 27,5 $\%$ dipengaruhi oleh faktor lain. Nilai koefisien korelasi sebesar 0,852 menunjukkan bahwa terdapat hubungan positif variabel bebas X (Minat belajar) terhadap variabel Y (kemampuan pemecahan masalah matematika). Angka koefisien korelasi tersebut menunjukkan bahwa setiap ada kenaikan satu nilai minat belajar peserta didik akan terdapat kenaikan kemampuan pemecahan msalah matematika sebesar 0,852. Akibatnya besarnya nilai minat belajar berpengaruh terhadap tingginya kemampuan pemecahan masalah matematika peserta didik.

Hal ini sesuai dengan pendapat Hodiyanto dalam penelitiannya menunjukkan bahwa terdapat hubungan positif yang signifikan antara minat belajar dengan kemampuan pemecahan masalah matematikapeserta didik (Kurnia et al. 2020). Menurut (Kurnia et al. 2020), minat belajar matematika peserta didik beragam dan hal ini disebabkan oleh faktor internal maupun faktor eksternal dari setiap peserta didik, diantaranya perhatian peserta didik terhadap pelajaran, cita-cita, bakat, motivasi, lingkungan dan proses pembelajaran matematika saat di sekolah itu sendiri. 


\section{KESIMPULAN}

Berdasarkan hasil penelitian yang telah dilakukan, maka didapatkan kesimpulan bahwa : terdapat pengaruh yang signifikan antara minat belajar terhadap kemampuan pemecahan masalah matematika peserta didik dan terdapat korelasi positif yang siginifikan antara minat belajar dan kemampuan pemecahan masalah matematika peserta didik. Dengan kata lain, semakin tinggi minat belajar matematika peserta didik maka akan mempengaruhi peningkatan kemampuan pemecahan masalah peserta didik. Oleh karena itu, seorang guru hendaknya dapat menciptakan suasana pembelajaran yang dapat menumbuhkan minat belajar peserta didik dan memberikan stimulasi kepada peserta didik untuk dapat lebih menyenangi mata pelajaran matematika selama proses pembelajaran matematika serta peran aktif orang tua untuk membantu proses pembelajaran peserta didik khususnya pada mata pelajaran matematika.

\section{REFERENSI}

Agustin, Putri Tiya Fitri, and Setyo Hartanto. 2018. "Pengaruh Minat Belajar Dan Kecemasan Matematis Terhadap Kemampuan Pemecahan Masalah." Jurnal Pendidikan Dan Pembelajaran Matematika (JP2M) 4(1):92-98.

Awaliyah, Winda, and Aflich Yusnita Fitrianna. 2018. "Hubungan Minat Belajar Terhadap Kemampuan Penalaran Matematik Siswa Smp Pada Materi Lingkaran.” JPMI (Jurnal Pembelajaran Matematika Inovatif) 1(2):93-98. doi: 10.22460/jpmi.v1i2.p93-98.

Friantini, Rizki Nurhana, and Rahmat Winata. 2019. "Analisis Minat Belajar Pada Pembelajaran Matematika." JPMI (Jurnal Pendidikan Matematika Indonesia) 4(1):6. doi: 10.26737/jpmi.v4i1.870.

Hermaini, Junika, and Erdawati Nurdin. 2020. "Bagaimana Kemampuan Pemecahan Masalah Matematis Siswa Dari Perspektif Minat Belajar ?” Journal for Research in Mathematics Learning 3(2):141-48.

Holidun, Holidun, Rubhan Masykur, Suherman Suherman, and Fredi Ganda Putra. 2018. "Kemampuan Pemecahan Masalah Matematis Kelompok Matematika Ilmu Alam Dan Ilmu-Ilmu Sosial.” Desimal: Jurnal Matematika 1(1):29. doi: 10.24042/djm.v1i1.2022.

Kurnia, Dedyerianto, Ety Nur Inah, and Tandri Patih. 2020. "Hubungan Minat Belajar Dengan Kemampuan Pemecahan Masalah Matematis Siswa Kelas VIII SMP Negeri 6 Buton Tengah.” Kulidawa 1(2):61-64.

Mayasari, Dian. 2019. "Penggunaan Matematika Realistik Melalui Media Autograph Untuk Meningkatkan Minat Dan Pemecahan Masalah Matematis.” Musamus Journal of Mathematics Education 2(1):12-21. doi: 10.35724/mjme.v2i1.1812.

Mutakin, T.Z., \& Cleopatra, M. 2015. Suplemen Aplikasi Komputer Dalam Penyusunan Karya Ilmiah. Tangerang: Pustaka Mandiri.

Nisrina, Nada. 2018. "Pengaruh Minat Dan Motivasi Belajar Terhadap Kemampuan Pemecahan 
Masalah Matematik.” 1(3):294-303.

Partayasa, Wayan, I. Gusti Putu Suharta, and I. Nengah Suparta. 2020. "Pengaruh Model Pembelajaran

Creative Problem Solving (CPS) Berbantuan Video Pembelajaran Terhadap Kemampuan

Pemecahan Masalah Ditinjau Dari Minat.” JNPM (Jurnal Nasional Pendidikan Matematika) 4(1):168-79. doi: 10.33603/jnpm.v4i1.2644.

Roebyanto, Gunawan, and Sri Harmini. 2017. Pemecahan Masalah Matematika. Bandung: PT Remaja Rosdakarya.

Supardi. 2017. Aplikasi Statistik Dalam Penelitian Edisi Revisi. Jakarta: Change Publication.

Suparman. 2014. Aplikasi Komputer Dalam Penyusunan Karya Ilmiah. Tangerang: Pustaka Mandiri.

Ulya, Himmatul. 2015. "Hubungan Gaya Kognitif Dengan Kemampuan Pemecahan Masalah Matematika Siswa." Jurnal Konseling GUSJIGANG 1(2).

Yuliasari, Evi. 2017. “Eksperimentasi Model PBL Dan Model GDL Terhadap Kemampuan Pemecahan Masalah Matematis Ditinjau Dari Kemandirian Belajar." JIPM (Jurnal Ilmiah Pendidikan Matematika) 6(1):1. doi: 10.25273/jipm.v6i1.1336. 